\title{
The effectiveness of retreatment with peginterferon alfa and ribavirin in patients with chronic viral hepatitis $C$ genotype 2 and 3: a prospective cohort study in Brazil
}

\author{
Simara Artico ${ }^{1,2^{*}+}$, Karine Medeiros Amaral ${ }^{1,2+}$, Candice Beatriz Treter Gonçalves ${ }^{1,2+}$ and Paulo Dornelles Picon ${ }^{1,2,3,4+}$
}

\begin{abstract}
Background: More than $50 \%$ of patients infected with chronic hepatitis C virus (HCV) do not respond to treatment with conventional interferon (IFN) combined with ribavirin (RBV). The aim of our study was to evaluate the effectiveness of retreatment with peginterferon alfa-2a or 2b (PEG-IFN 2a or 2b) concomitantly with RBV in patients with HCV genotype 2 and 3, which were non-responders or relapsers to initial treatment with IFN / RBV and to identify possible predictors of sustained virological response (SVR).

Methods: From September 2003 to March 2009 a cohort of 216 patients who had previously failed therapy with a regimen of standard interferon and ribavirin, were followed in a specialized service implemented in the Brazilian Unified Health System, Rio Grande do Sul. All patients were retreated with PEG-IFN 2a or 2b per week, associated with RBV, through oral route, with doses determined according to weight $(1,000 \mathrm{mg}$ if weight $\leq 75 \mathrm{Kg}$ and $1,250 \mathrm{mg}$ if $\geq 75 \mathrm{Kg}$ ) per day for 48 weeks. The HCV-RNA was tested by Polymerase Chain Reaction (PCR). Virological Response (VR) within 48 weeks and SVR in the 72 weeks was considered for evaluation of treatment efficacy. Analyses were performed in patients who received at least one dose of PEG-IFN.

Results: The SVR rate for non-responders to previous treatment was $34.4 \%$ and for relapsers was $50 \%(p=0.031)$. As predictive factors that contribute to improve SVR, were identified the age $(p=0.005)$, to be relapsers to previous treatment $(p=0.023)$ and present liver biopsy examination Metavir F0-F2 $(p=0.004)$. In assessing the safety profile, 51 patients (23.6\%) discontinued treatment prematurely.

Conclusions: This alternative retreatment for patients who have failed prior therapies for anti-HCV, has demonstrated promising SVR rate, provided that it includes a careful selection of patients with predictors of response and adverse events monitored.
\end{abstract}

Keywords: Hepatitis C, Retreatment, Peginterferon alpha, Ribavirin

\section{Background}

Since identification of its causative agent in 1989, hepatitis $\mathrm{C}$ has been recognized as a major public health problem, with major economic and quality of life impact on peoples [1]. The hepatitis $\mathrm{C}$ virus (HCV) is currently the leading cause of chronic hepatitis and is a major cause of cirrhosis

\footnotetext{
* Correspondence: simaraartico@ibest.com.br

${ }^{\dagger}$ Equal contributors

'Universidade Federal do Rio Grande do Sul (UFRGS), Porto Alegre, Brazil ${ }^{2}$ Centro de Monitorização de Medicamentos Injetáveis (CAMMI), Hospital Sanatório Partenon, Porto Alegre, RS, Brazil

Full list of author information is available at the end of the article
}

worldwide [2]. It is estimated that about $3 \%$ of world population are chronically infected by this agent, with at least six types of viral genotypes. In Brazil, are found mainly genotypes $1 \mathrm{a}, 1 \mathrm{~b}, 2 \mathrm{a}, 2 \mathrm{~b}$ and 3 , with a predominance of genotype 1 over non-1 genotypes, with distribution of $60 \%$ and $40 \%$, respectively. Among patients diagnosed in Brazil with non-1 genotype, approximately in $25 \%$ it is observed genotype 3 and $5 \%$ are diagnosed with genotype 2 [3].

Initially, the ideal treatment for chronic hepatitis $\mathrm{C}$ was the use of interferon alpha (IFN- $\alpha$ ) monotherapy at a dose of 3 million units, thrice a week for 48 weeks, with rates of 
sustained virological response (SVR) of only 12 to $16 \%$ [4-8]. Shortly after, there are several clinical studies demonstrating the superiority of combination therapy with ribavirin (RBV) on IFN- $\alpha$ monotherapy and in 1998 the scheme is approved by the Food and Drug Administration (FDA) for treatment of chronic viral hepatitis C. Using this combined regimen for 24 or 48 weeks resulted in an increase of 2 to 3 times the SVR rates ranging from $36 \%$ to $47 \%$ [9-11].

More recently, the incorporation of an inert molecule of polyethylene glycol molecule to IFN produced a new drug to treat hepatitis $\mathrm{C}$, peginterferon alfa ( $2 \mathrm{a}$ or $2 \mathrm{~b}$ ) with reduced kidney clearance (slower elimination), altered metabolism (more slow absorption) and increase in halflife, allowing his administration to become once a week instead of three times [12-14]. Using this new molecule has shown SVR rates of $54 \%$ to $56 \%$, according to some clinical trials [15-17].

When the pegylated interferon was introduced in the market, a sizeable proportion of patients had not yet been successful with conventional interferon-based regimens. As chronic hepatitis $\mathrm{C}$ virus infection can result in long term complications (cirrhosis, terminal liver failure and hepatocellular carcinoma), those patients remain at risk of developing progressive liver disease and the possibility of an alternative to retreatment has been the focus of clinical investigations [18-20]. Literature data show that it has been achieved a global response to retreatment of 30-60\% [21-32].

In Brazil, according to Chronic Viral Hepatitis C Therapeutic Guideline (CVH-PTG) - Ministerial Decree $\mathrm{N}^{\circ} .863$ of November 4, 2002, the standard treatment of hepatitis $C$ genotype 2 and 3 should be done with interferon alfa-2a (IFN-2a) or interferon alfa-2b (IFN-2b) at a dose of 3 million units, thrice a week subcutaneously combined with an oral dose ribavirin: $1,000 \mathrm{mg} /$ day for patients under $75 \mathrm{~kg}$ and 1,250 mg/day, for those weighing over $75 \mathrm{Kg}$ for 24 weeks. This drug is provided free by the Ministry of Health in capsules of $250 \mathrm{mg}$. For patients with hepatitis $C$ genotype 1 , with higher resistance to antiviral therapy, the recommended standard treatment is with peginterferon alfa-2a (PEG-IFN-2a) at a dose of $180 \mu \mathrm{g}$ or peginterferon alfa-2b (PEG-IFN-2b) at a dose of $1.5 \mu \mathrm{g} / \mathrm{Kg}$ body weight once a week subcutaneously, associated with an oral dose ribavirin: 1,000 $\mathrm{mg} /$ day for patients under $75 \mathrm{~kg}$ and 1,250 mg/day, for those weighing over $75 \mathrm{Kg}$ for 48 weeks [33]. On September 28, 2007, through the publication of Ordinance $\mathrm{N}^{\circ}$. 34, this Guideline was updated, including the use of PEG-IFN-2a or $2 \mathrm{~b}$ as the standard treatment in the retreatment of patients genotypes 2 and 3 non-responders or relapsed after treatment with interferon alfa and ribavirin [34].

For the effective implementation of CVH-PTG, the State Health Secretariat of Rio Grande do Sul/Brazil established in Parthenon Sanatorium Hospital (PSH), the first Center for Application and Monitoring of Injectable Drugs (CAMID), a service aimed at the care of patients with hepatitis $C$. This service is aimed at improving the pharmaceutical assistance with the implementation of pharmaceutical care to administer and systematically monitor patients receiving PEG-IFN and ribavirin [35].

Therefore, the aim of this study was to evaluate the effectiveness of retreatment with peginterferon alfa-2a or 2b combined with ribavirin for 48 weeks in patients with chronic hepatitis $\mathrm{C}$ non-responders or relapsers to previous treatment with interferon alfa who were followed by a pharmaceutical care program of the State Department of Health of Rio Grande do Sul/Brazil and to identify possible predictors of SVR.

\section{Methods \\ Design}

All patients with chronic hepatitis $\mathrm{C}$ genotypes 2 and 3 were studied in a prospective cohort study in the CAMID Parthenon Sanatorium Hospital from September 2003 to March 2009.

\section{Patient selection}

All Two hundred and sixteen patients with chronic hepatitis $C$ genotype 2 and 3 who underwent the first treatment for 24 weeks with interferon alfa-2a or $2 b$ at a dose of 3 million units thrice a week subcutaneously and oral dose daily ribavirin (1,000 or 1,250 $\mathrm{mg}$, depending on body weight). Out of these, 128 patients never achieved undetectable HCV RNA serum levels (qualitative PCR testing) during the first treatment (non-responders) and 88 patients showed undetectable HCV RNA during the first therapy but became HCV RNA positive after discontinuing medication (relapsers). All patients enrolled in the study who received at least one dose of medication were included in the statistical analysis. The study excluded all patients who did not agree to participate in interviews of monitoring during treatment.

\section{Sampling}

Patients in the study were sequentially allocated according to demand.

\section{Follow-up of patients and data collection}

The monitoring of patients was performed by a multidisciplinary team, with the presence of the pharmacist through monthly interviews. In these interviews, patients were informed about the disease, treatment and monitored for adverse events and laboratory tests needed for continuing care. The nursing staff performed the weekly applications of PEG-IFN, monthly monitoring body weight for possible dose adjustments where necessary. 
Patient information and interventions were recorded on a specific Pharmacotherapeutics file, which contributed to the clinical and laboratory data such as prior treatment hepatitis $C$, virus $C$ genotype, comorbidities, use of other medications, alcohol use, initial laboratory tests [albumin, prothrombin time, bilirubin, glucose, uric acid, ALT, AST, creatinine levels, TSH, hemoglobin and platelets]. An initial quantitative PCR and liver biopsy for assessing inflammatory activity and fibrosis grade were evaluated by the Metavir score. Patients were considered as carriers of non significant fibrosis when classified as F0, F1 and F2. Patients with F3 and F4 were considered as significant fibrosis carriers. that were recorded on the database developed especially for the service, allowing the pharmacoepidemiological study data [35].

As material to support the process of pharmaceutical care was used a "Patient Orientation Guide" containing information that was conveyed orally and in writing to the patient [35].

Adverse events presented by the patients were collected in a systematic way of monthly interviews with structured questions in advance, first questioning the patient about his condition and then about possible previously reported effects. The events were also classified according to intensity as mild, moderate or severe.

According to the protocol of the Ministry of Health, the quantitative PCR test at 12 weeks or 24 weeks in the qualitative PCR determined whether to proceed the treatment. Those patients who did not decrease by at least $2 \log$ the viral load became negative or had their treatment suspended. Treatment response was evaluated by qualitative PCR tests of the end of treatment (48 weeks Virological Response - VR) and 24 weeks after its completion (72 weeks Sustained Virological Response - SVR) [33].

The interventions performed during the monitoring of treatment were backed by the Ministerial Decree $\mathrm{N}^{\circ}$. 863 of November 4, 2002, the first edition of the Brazilian protocol that established the treatment of hepatitis $C$ with peginterferon alfa in the National Health System [33] and the Ministerial Decree $N^{\circ} .34$ of 28 November 2007, an update of the first ordinance described above [34].

\section{Treatment}

All study participants $(n=216)$ were retreated with peginterferon alfa-2a (PEG-IFN-2a) at a dose of $180 \mu \mathrm{g}$ or peginterferon alfa-2b (PEG-IFN-2b) at a dose of $1.5 \mu \mathrm{g} / \mathrm{kg}$ body weight, once a week subcutaneously, associated with an oral dose ribavirin: 1,000 mg/day for patients under $75 \mathrm{~kg}$ and 1,250 $\mathrm{mg} /$ day, for those weighing over $75 \mathrm{Kg}$ for 48 weeks. The doses of PEG-IFN and ribavirin were adjusted because of adverse effects and as medical advice.

\section{Effectiveness and safety}

A quantitative PCR test was obtained at week 12 of retreatment with the objective of observing a reduction of at least $2 \log _{10}$ in viral load compared to the result of pretreatment. Some patients also showed the qualitative PCR test at 24 weeks of retreatment, and if the result was positive there should be discontinuation of treatment.

For the efficacy analysis percentage of virological response (VR) and sustained virological response (SVR) were calculated.

We studied the predictive value of various parameters such as gender, age, body mass index, initial viral load, type of response to previous treatment (non-responder and relapsed), grade of hepatic fibrosis and transaminases regarding response to treatment (SVR).

The main safety parameters analyzed from the patients' reports on monthly interviews were body weight, adverse events and laboratory tests (neutropenia / neutrophils count $<750 / \mathrm{mm}^{3}$, leucopenia / leukocytes count $<1.500 / \mathrm{mm}^{3}$ and thrombocytopenia / platelet count $<50.000 / \mu \mathrm{L}$, anemia / hemoglobin level $<8.5 \mathrm{~g} / \mathrm{dL}$, creatinine, TSH, ALT e AST levels) and total discontinuation due to adverse events. We also analyzed the adverse events that led to discontinuation of treatment.

\section{Statistical analysis}

We performed a descriptive analysis of demographic and clinical variables, and SVR. For quantitative variables we used the mean and standard deviation (symmetric distribution) or median and interquartile range (asymmetric distribution). For the qualitative variables were used as absolute and relative frequencies. The SVR rate was compared in different groups using the chi-square test or Fisher exact test. Follow-up losses were treated as treatment failures.

For comparison of means was applied Student $t$ test for independent samples (eg average age between SVR and failure in SVR). In case of asymmetry, the Mann-Whitney test was used (e.g. median ALT initial between SVR and failure in SVR).

In multivariate analysis, the assessment of factors independently associated with SVR rate was applied to the Poisson regression analysis. The criterion for entering the variable in the model was to produce a $\mathrm{p}$ value less than 0.20 in bivariate analysis. We calculated relative risks (RR) and corresponding 95\% confidence.

The level of significance was $5 \%(\mathrm{p} \leq 0.05)$ and analyses were performed using Statistical Package for Social Sciences (SPSS) version 17.0.

\section{Ethical aspects}

This project was approved by the Ethics Committee of the School of Public Health of Rio Grande do Sul/Brazil, under number 421/08. All subjects signed a consent form in 
which information was provided on risks and benefits of the drug and confidentiality of data.

\section{Results}

\section{Patient characteristics}

Between September 2003 and March 2009, 216 patients were included in the study. All patients had viral genotype $2(5.6 \%)$ or three $(94.4 \%)$ and had been treated before for at least 24 weeks with conventional interferon in combination with ribavirin. The demographic, virological and histological characteristics of the sample are presented in Table 1 Out of the 216 patients, 123 (56.9\%) were male and mean age between genders was $53.6 \pm 9.0$ years. More than half had a viral load over $800.000 \mathrm{UI} / \mathrm{mL}(64.5 \%)$, and the mean body mass index (BMI) was $27.5 \pm 4.7 \mathrm{~kg} / \mathrm{m} 2$ among patients.

The completion of the examination of the liver biopsy showed fibrosis and inflammatory activity and results were presented according to the classification of Metavir. Out of the 216 patients retreated it was possible to determine the degree of fibrosis in 196 patients and the inflammatory activity of 170 patients. Forty-seven (24\%) had fibrosis grade F0-F2 and 149 patients (76\%) had fibrosis F3-F4 (Table 1).

Table 1 Baseline characteristics of patients

\begin{tabular}{|c|c|}
\hline Characteristics & $\begin{array}{l}\text { Number of patients } \\
\qquad(n=216)\end{array}$ \\
\hline Gender, M/F (\%male) & 123/93 (56.9) \\
\hline Age $(y r s)($ mean $\pm S D) *$ & $53.6 \pm 9.0$ \\
\hline Initial Weight $(\mathrm{Kg})(\text { mean } \pm \mathrm{SD})^{*}$ & $76.4 \pm 14.0$ \\
\hline $\mathrm{BMI}(\mathrm{Kg} / \mathrm{m} 2)(\text { mean } \pm \mathrm{SD})^{*}$ & $27.5 \pm 4.7$ \\
\hline \multicolumn{2}{|l|}{ Median Aminotrasferase levels. U/L (range) ${ }^{* *}$} \\
\hline Baseline Alanine aminotrasferase (ALT) & $95(61-165)$ \\
\hline Baseline Aspartate aminotransferase (AST) & $84.5(52-123)$ \\
\hline HCV Genotype, n (\%) & $n=216$ \\
\hline Genotype 2 & $12(5.6)$ \\
\hline Genotype 3 & $204(94.4)$ \\
\hline Response to previous treatment, $\mathrm{n}(\%)$ & $n=216$ \\
\hline Non-responders & $128(59.3)$ \\
\hline Relapsers & $88(40.7)$ \\
\hline Histological diagnosis, n (\%)*** & $n=196$ \\
\hline Fibrosis stage $0-2$ & $47(24.0)$ \\
\hline Fibrosis stage $3-4$ & $149(76.0)$ \\
\hline $\begin{array}{l}\text { Baseline serum HCV RNA }(\mathrm{IU} / \mathrm{mL}) \text {, } \\
\mathrm{n}(\%)^{* * * *}\end{array}$ & $n=155$ \\
\hline$<800.000$ & $55(35.5)$ \\
\hline$\geq 800.000$ & $100(64.5)$ \\
\hline
\end{tabular}

*Mean \pm standard deviation.

**Median (range percentile $25-75$ ).

***Twenty missing (9.3\%).

****Sixty-one missing (28.2\%).
Out of the patients who participated in the study 128 $(59.3 \%)$ were classified as non-responders and 88 (40.7\%) as relapsers to previous therapy with conventional interferon combined with ribavirin (Table 1).

\section{Safety evaluation}

The reasons for treatment interruption are shown in Table 2 . In the total sample $51(23.6 \%)$ patients prematurely discontinued treatment. A percentage of $18.5 \%$ the withdrawal was due to adverse events, $2.3 \%$ for presenting Qualitative PCR positive at week 24 of treatment and 2.8\% for other reasons such as no reduction in viral load at 12 weeks of treatment and withdrawal by the patient. The need for dose reduction of peginterferon alfa and/or ribavirin due to laboratory abnormalities (anaemia, neutropenia or thrombocytopenia) occurred in 28 (13\%) patients.

Tables 3 and 4 present the adverse events that led to discontinuation of treatment. Laboratory abnormalities were the event that led to more treatment interruption $(40 \%)$ and thrombocytopenia and leukopenia or neutropenia were more frequent than anemia. The death was the second most frequent event (20\%). The decompensated cirrhosis, characterized by encephalopathy and ascites, representing $17.5 \%$ of these interruptions. The other events leading to discontinuation were disabling symptoms (fatigue, malaise, diarrhea) (10\%), acute renal failure (7.5\%), psychiatric disorders $(5.0 \%)$, psoriasis $(2.5 \%)$ and diagnosis of hepatocellular carcinoma (2.5\%).

\section{Viral response and SVR predictive factors}

One hundred sixty-five patients (76.4\%) completed 48 weeks of retreatment. The overall rate obtained from ETR was 140/216 (64.8\%) and from SVR was 88/216 (40.7\%). For the group of non-responders patients the ETR rate was 81/128 $(63.3 \%)$ and the group of relapsed patients the ETR rate was 59/88 (67\%), $\mathrm{p}=0.671$, not showing statistically significant difference between the two groups. In the evaluation of the SVR group of patients non-responders had a rate of $44 / 128$ (34.4\%) significantly lower than the SVR rate for the relapsers group 44/88 (50\%), $\mathrm{p}=0.031$ (Table 5).

Efficacy data for each group of parameters were analyzed separately in the bivariate analysis of possible predictors versus SVR and are presented in Table 6 The mean age of

Table 2 Reasons for discontinuation of treatment

\begin{tabular}{lc}
\hline Reasons for discontinuation & $\begin{array}{c}\text { Number of patients, } \\
\mathbf{n}(\%)\end{array}$ \\
\hline Adverse Events & $40(18.5)$ \\
No reduction of 2 log viral load at week 12 & $3(1.4)$ \\
Positive PCR qualitative at week 24 & $5(2.3)$ \\
Withdrawal of the patients & $3(1.4)$ \\
Total discontinuation of treatment & $51(23.6)$ \\
\hline
\end{tabular}


Table 3 Incidence of adverse events that caused discontinuation of treatment

\begin{tabular}{lc}
\hline Adverse events $(\mathbf{n}=\mathbf{4 0})$ & $\begin{array}{c}\text { Incidence of occurrence, } \\
\mathbf{n}(\%)\end{array}$ \\
\hline Laboratory abnormality & $16(40)$ \\
$\begin{array}{l}\text { Descompensated cirrhosis (ascites/ } \\
\text { encephalopathy) }\end{array}$ & $7(17.5)$ \\
Incapacitating symptoms & $4(10)$ \\
Acute Renal Failure & $3(7.5)$ \\
Psoriasis & $1(2.5)$ \\
Diagnosis of Hepatocellular carcinoma & $1(2.5)$ \\
Death & $8(20)$ \\
\hline
\end{tabular}

patients with SVR was $51.3 \pm 9.7$ years, significantly lower compared with the group of patients who failed to achieve SVR that was $55.2 \pm 8.2$ years $(\mathrm{p}=0.002)$.

When analyzed by gender, male patients showed a SVR rate 50/123 (40.7\%) females and 38/93 (40.9\%), $\mathrm{p}=1.000$, showing the same response profile. Among patients with initial BMI $<30 \mathrm{Kg} / \mathrm{m} 2$ or $\geq 30 \mathrm{Kg} / \mathrm{m} 2$ SVR rates were $41 /$ 104 (39.4\%) and 18/39 (46.2\%), $\mathrm{p}=0.591$, respectively, showing equal response between the groups. The mean baseline pre-treatment ALT of patients with SVR was $93 \pm$ $108 \mathrm{U} / \mathrm{L}$, not statistically significant difference if compared with the group of patients who failed to obtain that SVR was $97 \pm 110 \mathrm{U} / \mathrm{L}(\mathrm{p}=0.144)$. Among patients with histological diagnosis in liver biopsy F0-F2 fibrosis in the SVR rate was 29/47 (61.7\%) significantly increased compared with F3-F4 fibrosis where the SVR rate was 48/149 (32.2\%), $\mathrm{p}=0.001$. In assessing the baseline level of serum HCV RNA there was no significant difference between patients with baseline viral load $<800.000 \mathrm{UI} / \mathrm{mL}$ that showed SVR rate $25 / 55$ (45.5\%) compared with a baseline viral $\operatorname{load} \geq 800.000 \mathrm{IU} / \mathrm{mL}$ where the SVR rate was $41 / 100$ (41\%), $\mathrm{p}=0.714$.

In multivariate analysis, the assessment of factors independently associated with SVR rate was applied to the Poisson regression analysis, using as criteria for variable

Table 4 Incidence of major adverse events that caused discontinuation of treatment

\begin{tabular}{lc}
\hline Adverse events & Incidence of occurrence, $\mathbf{n ~ ( \% )}$ \\
\hline Laboratory abnormality & $\mathrm{n}=16$ \\
Anaemia & $11(68.7)$ \\
Thrombocytopenia/neutropenia & $15(93.7)$ \\
Death & $\mathrm{n}=8$ \\
Acute myocardial infarction & $1(12.5)$ \\
Pneumonia and sepsis & $2(25)$ \\
Acute respiratory failure & $2(25)$ \\
Encephalopathy/ascites & $2(25)$ \\
Cause unknown & $1(12.5)$ \\
\hline
\end{tabular}

Table 5 End-of-treatment and sustained virologic response rates in patients treated to week 48

\begin{tabular}{|c|c|c|}
\hline End-of-treatment response & $\begin{array}{l}\text { Patients treated } \\
n=216, n(\%)\end{array}$ & $p^{*}$ \\
\hline End-of-treatment Response at week 48, n (\%) & $140 / 216(64.8 \%)$ & \\
\hline Non-responder to initial treatment & $81 / 128(63.3 \%)$ & 0.671 \\
\hline Relapsed to initial treatment & $59 / 88(67 \%)$ & \\
\hline $\begin{array}{l}\text { Sustained Virologic Response at week } 72, \mathrm{n} \\
(\%)\end{array}$ & $88 / 216(40.7 \%)$ & \\
\hline Non-responder to initial treatment & $44 / 128(34.4 \%)$ & 0.031 \\
\hline Relapsed to initial treatment & $44 / 88(50 \%)$ & \\
\hline
\end{tabular}

* Significance based on Fisher's Exact test.

entry into the model p-value less than 0.20 bivariate analyses (Table 7). Thus, in this study were identified as predictors of SVR age (mean age $51.3 \pm 9.4$ years, $\mathrm{p}=0.005$ ), the type of response to previous treatment (non-responder or relapsed, $\mathrm{p}=0.023$ ) and degree fibrosis shown on histological diagnosis (fibrosis F0-F2 or F3-F4 fibrosis, $\mathrm{p}=0.004$ ), indicating that patients with less advanced age, relapsed to previous treatment and degree of fibrosis F0-F2 have a better chance of obtaining SVR. For the analysis of variable average initial pretreatment ALT $(p=0.216)$ the difference was not statistically significant, indicating that this parameter, in this study did not contribute to increase the rate of SVR.

\section{Discussion}

Many patients with chronic hepatitis $C$ have not yet been able to obtain SVR with anti-HCV therapies, and thus become a candidate likely to develop progressive liver disease in the long term, such as cirrhosis or HCC with the possibility of needing liver transplantation [18-20]. Thus, infection in patients with chronic hepatitis $\mathrm{C}$ relapsers or non-responders to previous therapy has been an important public health problem and the possibility of an alternative to retreatment has been the focus of clinical investigations.

So, this cohort study was able to assess the effectiveness of retreatment with peginterferon alfa in patients with chronic hepatitis $\mathrm{C}$ genotype 2 or 3 in a healthcare environment of the Brazilian public health system. Baseline characteristics such as age, gender, initial body weight, body mass index and baseline ALT and AST, showed no differences from the baseline features presented in several published studies, indicating that the populations for these characteristics were similar.

In our study group of patients non-responders to previous therapy with interferon alfa combined with ribavirin showed an SVR rate of $34.4 \%$ when retreated with PEGIFN alpha-2a or $2 \mathrm{~b}$ combined with ribavirin for 48 weeks. This result is similar to that described by Sherman et al. who found an SVR rate of 37\% in non-responders retreated 
Table 6 Bivariate analyse of factors predictive of sustained virologic response (SVR)

\begin{tabular}{|c|c|c|c|c|}
\hline \multirow[t]{2}{*}{ Parameter } & \multirow{2}{*}{$\frac{n}{216}$} & \multirow{2}{*}{$\begin{array}{c}\text { SVR } \\
n=88\end{array}$} & \multirow{2}{*}{$\frac{\text { Failure SVR }}{n=128}$} & \multirow[t]{2}{*}{$\mathrm{p}^{*}$} \\
\hline & & & & \\
\hline Age (yrs) (mean $\pm S D)^{* *}$ & & $51.3 \pm 9.7$ & $55.2 \pm 8.2$ & 0.002 \\
\hline Gender & 216 & & & \\
\hline Male & 123 & $50(40.7 \%)$ & $73(59.3 \%)$ & 1.000 \\
\hline Female & 93 & $38(40.9 \%)$ & $55(59.1 \%)$ & \\
\hline BMI (Kg/m2) & 143 & & & \\
\hline$<30$ & 104 & $41(39.4 \%)$ & $63(60.6 \%)$ & 0.591 \\
\hline$\geq 30$ & 39 & $18(46.2 \%)$ & $21(53.8 \%)$ & \\
\hline Median Aminotrasferase levels, $(\mathrm{U} / \mathrm{L})^{* * *}$ & 215 & $\mathrm{n}=88$ & $n=127$ & \\
\hline ALT & & $93 \pm 108$ & $97 \pm 110$ & 0.144 \\
\hline Histological diagnosis**** & 196 & & & \\
\hline Fibrosis stage $0-2$ & 47 & $29(61.7 \%)$ & $18(38.3 \%)$ & 0.001 \\
\hline Fibrosis stage $3-4$ & 149 & $48(32.2 \%)$ & $101(67.8 \%)$ & \\
\hline Baseline serum HCV RNA (IU/mL) $)^{* * * *}$ & 155 & & & \\
\hline$<800.000$ & 55 & $25(45.5 \%)$ & $30(54.5 \%)$ & 0.714 \\
\hline$\geq 800.000$ & 100 & 41 (41.0\%) & 59 (59\%) & \\
\hline
\end{tabular}

* Significance based on qui-quadrado de Pearson test, t-student and Mann-Whitney. **Mean \pm standard deviation.

*** Median (interquartile range).

****Twenty missing (9.3\%).

*****Sixty-eight missing (31.5\%).

*****Sixty-one missing $(28,2 \%)$.

with PEG-IFN alpha-2a and RBV [30]. In the study of HALT-C Shiffman et al. to assess a sample of 604 patients and all non-responders with advanced fibrosis (METAVIR F3-F4) obtained SVR rate was 18\% [21] as well as the study of Carnicer et al. to assess a sample of 35 patients nonresponders, $17 \%$ with fibrosis $\mathrm{F} 3-\mathrm{F} 4$ and $45.8 \%$ with $\mathrm{HCV}$ RNA $>850.000 \mathrm{UI} / \mathrm{mL}$ showed an SVR rate of only $27.3 \%$ [22]. However, some multicenter studies, sponsored by pharmaceutical companies as Parise et al. with PEG-IFN alpha-2a plus RBV [23] and Krawitt EL et al. with PEG-IFN alpha-2b plus RBV [25], has demonstrated higher values in the SVR rates in patients non-responders to prior therapy of $46 \%$ and $57 \%$, respectively.

Table 7 Multivariate analyse of factors predictive of SVR through regression of poisson

\begin{tabular}{lcc}
\hline Parameter & RR (IC 95\%) & $\mathbf{p}^{*}$ \\
\hline Age (yrs) & $0.98(0.97-0.99)$ & 0.005 \\
ALT/TGO (U/I) & $1.00(0.99-1.01)$ & 0.216 \\
Histological diagnosis & & \\
$\quad$ Fibrosis stage 0-2 & $1.68(1.19-2.37)$ & 0.004 \\
$\quad$ Fibrosis stage 3-4 & 1.00 & \\
Response to previous treatment & & \\
$\quad$ Non-responders & 1.00 & 0.023 \\
$\quad$ Relapsers & $1.46(1.05-2.02)$ & \\
\hline
\end{tabular}

For the group of relapsed patients, in our study we found an SVR rate of $50 \%$. This result is confirmed favorably to the data presented in studies by Mathew et al. who found an SVR rate of $50 \%$ of patients relapsed when retreated with PEG-IFN alpha-2b plus RBV [27] as well as the study of Sherman et al. who found an SVR rate of $51 \%$ for relapsed patients, genotype 2 and 3 when retreated with PEG-IFN alpha-2a plus RBV [30]. Meanwhile, other authors have presented their studies in SVR rates for patients relapsed to prior therapy, superior to that found in our study, as presented by multicenter studies by Parise et al. PEG-IFN alpha-2a plus RBV [23] and Krawitt E.L et al. PEG-IFN alpha-2b plus RBV [25], SVR rates of 70\% and $59 \%$, respectively. Other studies also showed a higher SVR rate than our results, as well as the one presented by Basso et al. to portray patients with recurrent PEG-IFN alpha-2b plus RBV where the SVR rate achieved was 78.6\% [32] and Gonçalves Jr et al. who found an SVR rate of $62 \%$, to portray with PEG-IFN alpha- $2 \mathrm{~b}$ plus RBV a sample where only $26 \%$ of patients had liver diagnostics F3-F4 and 30\% had baseline viral load HCV RNA > $800.000 \mathrm{UI} / \mathrm{mL}$ [29].

According to Mitchell L. Shiffman clinical and virological factors may be useful to predict the likelihood of response to retreatment such as: type of response to previous treatment (non-responders or relapsers), race, type of viral genotype, liver disease severity, current alcohol consumption in which higher response rates can be obtained when 
patients are carefully selected. Therefore, we concluded that retreatment with PEG-IFN and RBV should be reserved for patients relapsed to prior therapy, which had been done with IFN- $\alpha$ monotherapy and in patients with viral genotype 2 and 3 [23].

Based on these previous findings, current studies of retreatment have evaluated the influence of factors predictive of SVR rates. In our study, among the evaluated parameter settings (type of response to previous treatment, age, gender, BMI, ALT, liver fibrosis and serum HCV RNA), only the type of response to previous treatment, age, the initial level of ALT and the degree of hepatic fibrosis, showed statistical significance in achieving SVR.

In the evaluation of factors independently associated with SVR rate was applied Poisson regression analysis and were identified as predictors of SVR: age, be relapsed to previous treatment and present degree of liver fibrosis F0-F2, indicating that these patients are more likely to have SVR. For the analysis of average initial pretreatment ALT variable was not statistically significant, indicating that this parameter in this study did not contribute to increase the rate of SVR.

These findings resemble those reported by Shiffman et al. that showed that in their multivariate regression analysis the following factors: previous treatment with IFN- $\alpha$ monotherapy, virus $\mathrm{C}$ genotype 2 and 3, a serum HCV RNA less than 1.5 million IU/mL, an AST: ALT ratio less than 1.0 and absence cirrhosis on liver biopsy as associated with an increased probability of achieving SVR [21].

Our results also are similar to those presented Sherman et al. Direct comparisons are difficult to achieve, since, Sherman et al. stratified the results among the group of relapsed patients and non-responders to initial treatment to assess predictors of SVR: in the group of relapsed patients, the predictors of SVR were HCV genotype 2 and 3, the Caucasian race and a low initial HCV viral load, and in the patients non-responders, were gender, body weight, BMI, degree of hepatic fibrosis and a low initial HCV viral load as predictors of SVR [30].

No association was found between parameters BMI $(<$ or $\geq 30 \mathrm{Kg} / \mathrm{m} 2)$ and baseline viral load of HCV RNA ( $<$ or $\geq 800.000 \mathrm{IU} / \mathrm{mL}$ ) at the rate of SVR. This lack of association probably could not be established in our study because the sample was lost for the two parameters of $33.8 \%$ and $28.2 \%$, respectively. Loss of data collection for these parameters represented a failure in data collection of the study, not allowing the establishment of relationship with SVR. The study of Sherman et al. identified as a predictor of SVR low initial load HCV RNA in both groups of patients as in nonresponders relapsed; whereas for this parameter only BMI was identified as a predictor of response in patients non-responders [30]. As the study of Sherman et al. and HALT-C study of Shiffman et al. also found that an initial viral load less than $1.500 .000 \mathrm{IU} / \mathrm{mL}$ is associated with an increased probability of SVR [21].

Our study showed that patients with less advanced age are more likely to respond to retreatment regimen, since the patients with SVR had a lower mean age (51.3 \pm 9.4 years) compared with patients who had failures in SVR with significantly higher mean age (55.2 \pm 8.2 years). This result was also observed by Krawitt et al. to identify nonresponders that patients aged 40 years or younger have a higher SVR rate, but for the group of relapsed patients, this significance was not found [25].

It is important to note the poor liver profile of these patients' with high percentage (76\% presented F3/F4) with results in liver biopsy can justify the number of interruptions of treatment and deaths from decompensated cirrhosis (ascites and encephalopathy) found in our study. Some effectiveness studies in the literature revealed different percentages described in cirrhotic patients, and international studies with a smaller percentage as observed by Carnicer et al. [22] and Sherman et al. [30] where 20\% and $26 \%$, respectively of the samples were composed of patients with cirrhosis. However, in studies in Brazil are found, generally higher percentages of patients with cirrhosis as shown by the studies of Gonçalves et al. [29] and Parise et al. $40 \%$ and $33 \%$ respectively of their samples composed of patients with cirrhosis [23].

The percentage of discontinuation due to adverse events (18.5\%) in our study was slightly different from controlled clinical studies (5-14\%) [36] but similar to studies of effectiveness $[21,25,27]$. This difference in profile is justified by the presence of comorbidities in this population when are conducted effectiveness studies that portray the reality of drug use, without prior selection of the sample. Almost a third of patients eligible to participate in clinical trials is excluded from the criteria established for inclusion and exclusion. Thus, patients with decompensated cirrhosis, hepatitis B, HIV, kidney disease, neuropsychiatric, coronary, cerebrovascular, or hematologic diseases are usually excluded from controlled clinical studies, favoring the non-appearance of adverse events associated with these comorbidities [36].

Eight patients died during the retreatment, representing $20 \%$ of interruptions due to adverse events. The causal relationship between death and retreatment has not been established. However, it is remarkable that in controlled clinical studies of effectiveness investigated there are no reports of death during the retreatment [21-32]. The average age of patients who died was 57.3 years and all had degree of liver fibrosis by F4 rating Metavir, characterizing the presence of cirrhosis in the whole population. These criteria may have compromised the continuity of treatment, as well as contributed to the evolutions for the deaths, but since these criteria are included in the general criteria for inclusion of patients candidates for retreatment 
with alfapeguinterferona + ribavirin in accordance with Ordinance No. 34 of 28 September 2007, the Ministry of Health of Brazil, we could not exclude these patients the possibility for retreatment. For this reason, studies like this, which represent the description of a population treated in real life, without prior sample selection, and was able to demonstrate in their analyzes the importance of establishing predictors of response, should be considered and made public in order to prevent individuals who are at risk of a treatment which will not benefit them, producing individual damage and to the public health system.

\section{Conclusions}

The results obtained in our sample suggest that there are benefits in portraying patients who failed therapy with interferon alfa and ribavirin, demonstrating that acceptable response rates, but not ideal yet, can be achieved in clinical practice. Patients non- responders to previous therapy had an SVR rate of $34.4 \%$ while relapsed patients a rate of $50 \%$ was obtained. The less advanced age, to be relapsing to previous treatment and present with liver biopsy fibrosis (F0-F2 Metavir) were identified as best predictors of SVR.

Concurrently with these findings the data safety profile of this treatment should be considered, since $18.5 \%$ of the reasons for prematurely discontinuation of treatment were due to adverse events, being the most frequent laboratory abnormalities (40\%) and death (20\%).

So, considering the severity of this clinical and epidemiological condition, it is necessary a careful selection of patients to retreatment, in order to accommodate patients who meet the criteria of predictive factors of SVR, in order to not to expose individuals to the risk of treatment that will not be benefited, producing individual damage and to the public health system.

\section{Abbreviations \\ ALT: Alanine aminotransferase; AST: Aspartate aminotransferase; BMI: Body mass index; CAMID: Center for Application and Monitoring of Injectable Drugs; CVH-PTG: Chronic Viral Hepatitis C Therapeutic Guideline; FDA: Food and Drug Administration; HCV: Hepatitis C virus; IFN: Interferon; IFN- 2a: Interferon alfa-2a; IFN-2b: Interferon alfa-2b; PCR: Polymerase Chain Reaction; PEG-IFN 2a: Peginterferon alfa-2a; PEG-IFN 2b: Peginterferon alfa-2b; PSH: Parthenon Sanatorium Hospital; RBV: Ribavirin; RFT: Percentage of virological response; RR: Relative risks; SPSS: Statistical Package for Social Sciences; SVR: Sustained virological response; VR: Virological response.}

\section{Competing interests}

The authors declare that they have no competing interests.

\section{Authors' contributions}

SA carried out the interviews pharmacotherapeutic monitoring, developed the database, performed the statistical analysis and drafted the manuscript. KA carried out the interviews pharmacotherapeutic monitoring and performed the statistical analysis. CG participated in the design of the study. PP conceived of the study, and participated in its design and coordination and helped to draft the manuscript. All authors read and approved the final manuscript.

\section{Acknowledgements}

The authors would like to thank the patients for their cooperation and availability

\section{Author details}

${ }^{1}$ Universidade Federal do Rio Grande do Sul (UFRGS), Porto Alegre, Brazil. ${ }^{2}$ Centro de Monitorização de Medicamentos Injetáveis (CAMMI), Hospital Sanatório Partenon, Porto Alegre, RS, Brazil. ${ }^{3}$ Department of Internal Medicine, Universidade Federal do Rio Grande do Sul (UFRGS), Hospital de Clínicas de Porto Alegre (HCPA), Porto Alegre, Brazil. ${ }^{4}$ Health Department of the State of Rio Grande do Sul, Porto Alegre, Brazil.

Received: 17 February 2012 Accepted: 13 December 2012

Published: 27 December 2012

\section{References}

1. Choo QL, Kuo G, Weiner AJ, Overby LR, Bradley DW, Houghton M: Isolation of a cDNA clone derived from a blood-borne non-a, non-B viral hepatitis genome. Science 1989, 244:359-362.

2. Alter MJ: The epidemiology of acute and chronic hepatitis C. Clin Liver Dis 1997, 1:559-568. vi-vii.

3. Relatório do Grupo de Estudos da Sociedade Brasileira de Hepatologia: Epidemiologia da infecção pelo vírus da hepatite C no Brasil [www.sbhepatologia.org.br].

4. Lauer GM, Walker BD: Hepatitis C virus infection. N Engl J Med 2001, 345:41-52.

5. Davis GL, Balart LA, Schiff ER, Lindsay K, Bodenheimer HC Jr, Perrillo RP, Carey W, Jacobson IM, Payne J, Dienstag JL, et al: Treatment of chronic hepatitis $\mathrm{C}$ with recombinant interferon alfa. A multicenter randomized, controlled trial. Hepatitis interventional therapy group. N Engl J Med 1989, 321:1501-1506.

6. Carithers RL Jr, Emerson SS: Therapy of hepatitis C: meta-analysis of interferon alfa-2b trials. Hepatology 1997, 26:83S-88S.

7. Marcellin P, Boyer N, Gervais A, Martinot M, Pouteau M, Castelnau C, Kilani A, Areias J, Auperin A, Benhamou JP, et al: Long-term histologic improvement and loss of detectable intrahepatic HCV RNA in patients with chronic hepatitis $C$ and sustained response to interferon-alpha therapy. Ann Intern Med 1997, 127:875-881.

8. Keeffe EB, Hollinger FB: Therapy of hepatitis C: consensus interferon trials. Consensus interferon study group. Hepatology 1997, 26:101S-1075.

9. MCHutchison JG, Gordon SC, Schiff ER, Shiffman ML, Lee WM, Rustgi VK, Goodman ZD, Ling MH, Cort S, Albrecht JK: Interferon alfa-2b alone or in combination with ribavirin as initial treatment for chronic hepatitis $\mathrm{C}$. Hepatitis interventional therapy group. N Engl J Med 1998, 339:1485-1492.

10. Poynard T, Marcellin P, Lee SS, Niederau C, Minuk GS, Ideo G, Bain V, Heathcote J, Zeuzem S, Trepo C, Albrecht J: Randomised trial of interferon alpha2b plus ribavirin for 48 weeks or for 24 weeks versus interferon alpha2 $\mathrm{b}$ plus placebo for 48 weeks for treatment of chronic infection with hepatitis $C$ virus. International hepatitis interventional therapy group (IHIT). Lancet 1998, 352:1426-1432.

11. Davis GL, Esteban-Mur R, Rustgi V, Hoefs J, Gordon SC, Trepo C, Shiffman $M L$, Zeuzem S, Craxi A, Ling MH, Albrecht J: Interferon alfa- $2 b$ alone or in combination with ribavirin for the treatment of relapse of chronic hepatitis C. International hepatitis interventional therapy group. N Engl J Med 1998, 339:1493-1499.

12. Foster GR: Review article: pegylated interferons: chemical and clinical differences. Aliment Pharmacol Ther 2004, 20:825-830.

13. Zeuzem S, Feinman SV, Rasenack J, Heathcote EJ, Lai MY, Gane E, O'Grady J, Reichen J, Diago M, Lin A, et al: Peginterferon alfa-2a in patients with chronic hepatitis C. N Engl J Med 2000, 343:1666-1672.

14. Lindsay KL, Trepo C, Heintges T, Shiffman ML, Gordon SC, Hoefs JC, Schiff ER, Goodman ZD, Laughlin M, Yao R, Albrecht JK: A randomized, doubleblind trial comparing pegylated interferon alfa- $2 \mathrm{~b}$ to interferon alfa- $2 \mathrm{~b}$ as initial treatment for chronic hepatitis C. Hepatology 2001, 34:395-403.

15. Fried MW, Shiffman ML, Reddy KR, Smith C, Marinos G, Goncales FL Jr, Haussinger D, Diago M, Carosi G, Dhumeaux D, et al: Peginterferon alfa-2a plus ribavirin for chronic hepatitis C virus infection. N Engl J Med 2002, 347:975-982.

16. Manns MP, McHutchison JG, Gordon SC, Rustgi VK, Shiffman M, Reindollar R, Goodman ZD, Koury K, Ling M, Albrecht JK: Peginterferon alfa-2b plus ribavirin compared with interferon alfa-2b plus ribavirin for initial 
treatment of chronic hepatitis C: a randomised trial. Lancet 2001, 358:958-965.

17. Hadziyannis SJ, Sette H Jr, Morgan TR, Balan V, Diago M, Marcellin P, Ramadori G, Bodenheimer H Jr, Bernstein D, Rizzetto M, et al: Peginterferon-alpha2a and ribavirin combination therapy in chronic hepatitis $C$ : a randomized study of treatment duration and ribavirin dose. Ann Intern Med 2004, 140:346-355.

18. El-Serag HB, Mason AC: Rising incidence of hepatocellular carcinoma in the united states. N Engl J Med 1999, 340:745-750.

19. National Institutes of Health Consensus Development Conference Statement: Management of hepatitis C: 2002-june 10-12, 2002. Hepatology 2002, 36:S3-20.

20. International EASL: Consensus conference on hepatitis C. Paris, 26-28, february 1999, consensus statement. European association for the study of the liver. J Hepatol 1999, 30:956-961.

21. Shiffman ML, Di Bisceglie AM, Lindsay KL, Morishima C, Wright EC, Everson GT, Lok AS, Morgan TR, Bonkovsky HL, Lee WM, et al: Peginterferon alfa-2a and ribavirin in patients with chronic hepatitis $C$ who have failed prior treatment. Gastroenterology 2004, 126:1015-1023. discussion 1947.

22. Carnicer F, Zapater P, Gutierrez A, Garcia A, Ruiz F, Lopez M: Treatment with pegylated interferon alpha-2b and ribavirin in patients unresponsive to previous treatments with standard interferon as monotherapy or combined with ribavirin. Rev Esp Enferm Dig 2005, 97:306-316.

23. Parise $E$, Cheinquer $H$, Crespo D, Meirelles A, Martinelli A, Sette H, Gallizi J, Silva R, Lacet C, Correa E, et al: Peginterferon alfa-2a (40KD) (PEGASYS) plus ribavirin (COPEGUS) in retreatment of chronic hepatitis $C$ patients, nonresponders and relapsers to previous conventional interferon plus ribavirin therapy. Braz J Infect Dis 2006, 10:11-16.

24. Shiffman ML: Retreatment of patients with chronic hepatitis $C$. Hepatology 2002, 36:S128-134.

25. Krawitt EL, Ashikaga T, Gordon SR, Ferrentino N, Ray MA, Lidofsky SD: Peginterferon alfa- $2 \mathrm{~b}$ and ribavirin for treatment-refractory chronic hepatitis C. J Hepatol 2005, 43:243-249.

26. Taliani G, Gemignani G, Ferrari C, Aceti A, Bartolozzi D, Blanc PL, Capanni M, Esperti $F$, Forte $P$, Guadagnino $V$, et al: Pegylated interferon alfa-2b plus ribavirin in the retreatment of interferon-ribavirin nonresponder patients. Gastroenterology 2006, 130:1098-1106.

27. Mathew A, Peiffer LP, Rhoades K, McGarrity T: Sustained viral response to pegylated interferon alpha- $2 \mathrm{~b}$ and ribavirin in chronic hepatitis $\mathrm{C}$ refractory to prior treatment. Dig Dis Sci 2006, 51:1956-1961.

28. Herrine SK, Brown RS Jr, Bernstein DE, Ondovik MS, Lentz E, Te H: Peginterferon alpha-2a combination therapies in chronic hepatitis $C$ patients who relapsed after or had a viral breakthrough on therapy with standard interferon alpha-2b plus ribavirin: a pilot study of efficacy and safety. Dig Dis Sci 2005, 50:719-726.

29. Goncales FL Jr, Moma CA, Vigani AG, Angerami AF, Goncales ES, Tozzo R, Pavan MH, Goncales NS: Retreatment of hepatitis C patients with Pegylated interferon combined with ribavirin in non-responders to interferon plus ribavirin. Is it different in real life? BMC Infect Dis 2010, 10:212.

30. Sherman M, Yoshida EM, Deschenes M, Krajden M, Bain VG, Peltekian K, Anderson F, Kaita K, Simonyi S, Balshaw R, Lee SS: Peginterferon alfa-2a (40KD) plus ribavirin in chronic hepatitis $C$ patients who failed previous interferon therapy. Gut 2006, 55:1631-1638.

31. Camma C, Bruno S, Schepis F, Lo lacono O, Andreone P, Gramenzi AG, Mangia A, Andriulli A, Puoti M, Spadaro A, et al: Retreatment with interferon plus ribavirin of chronic hepatitis $C$ non-responders to interferon monotherapy: a meta-analysis of individual patient data. Gut 2002, 51:864-869.

32. Basso M, Torre F, Grasso A, Percario G, Azzola E, Artioli S, Blanchi S, Pelli N, Picciotto A: Pegylated interferon and ribavirin in re-treatment of responder-relapser HCV patients. Dig Liver Dis 2007, 39:47-51.

33. Sander GB, Kuchenbecker RS, Amaral KM, Krug BC, Picon PD: Hepatite Vira Crônica C. In In Protocolos clínicos e diretrizes terapêuticas - medicamentos excepcionais. Edited by Picon PD, Beltrame A. Porto Alegre: Gráfica Palotti; 2002:431-454

34. da Saúde M: Portaria n 34, de 28 de setembro de 2007. Dispõe sobre Protocolo Clínico e Diretrizes Terapêuticas para Hepatite Viral Crônica C. In Book Portaria no 34, de 28 de setembro de 2007. Dispõe sobre Protocolo
Clínico e Diretrizes Terapêuticas para Hepatite Viral Crônica C. City: Diário Oficial da União, Poder Executivo; 2007.

35. Amaral KM, Reis JG, Picon PD: Atenção farmacêutica no sistema único de saúde: um exemplo de experiência bem sucedida com pacientes portadores de hepatite C. Rev Bras Farm 2006, 87:19-21.

36. Strader DB: Understudied populations with hepatitis C. Hepatology 2002, 36:S226-236.

doi:10.1186/1471-2334-12-377

Cite this article as: Artico et al:: The effectiveness of retreatment with peginterferon alfa and ribavirin in patients with chronic viral hepatitis $C$ genotype 2 and 3: a prospective cohort study in Brazil. BMC Infectious Diseases 2012 12:377.

\section{Submit your next manuscript to BioMed Central and take full advantage of:}

- Convenient online submission

- Thorough peer review

- No space constraints or color figure charges

- Immediate publication on acceptance

- Inclusion in PubMed, CAS, Scopus and Google Scholar

- Research which is freely available for redistribution 